\title{
THE ROLE OF URBAN SUFISM OF SHALAWAT MUHAMMAD ASSEMBLY ON URBAN MIDDLE CLASS SOCIETY
}

\author{
Rubaidi \\ Universitas Islam Negeri SunanAmpel Surabaya, Indonesia \\ robetmugabe@yahoo.com \\ Article history: \\ Submitted: 12-03-2018 | Revised: 20-08-2018 | Accepted: 15-11-2018
}

\begin{abstract}
This article critically examines the role of Sufism in the process of social change in society, especially among urban societies that are symbolized by their middle class society. The subject in this study is the Shalawat Muhammad Assembly under Mursyid Gus Kahar and his successor, Gus Mustakim. Although the assembly represents the urban sufism, but it has rooted from classical Sufism. In analyzing the role of this assembly in the process of social change in society, the theoretical framework of Cultural Brokers and Cultural Trendsetter of Geertz and Hirokosi are used as perspectives. The result simultaneously, consistently, and progressively shows that Sufism has a major contribution in any social change of societies to the value and ideology from the outside. The inherent value system in Sufism symbolized by the guru (murshid), is not just a role as a cultural broker as mentioned by the theory of Geertz. In fact, all gurus (mursyid) are willing to change the value and ideology from the outside into a new system of traditions and cultures. This phenomenon resembles the cultural role of kyai in the Islamization of Indonesia in the past. It is the same like the theory of the cultural trendsetter of Hirokosi.
\end{abstract}

Keywords: Urban Sufism, Shalawat Muhammad Assembly, Social change, Cultural Broker and Cultural Trendsetter

\begin{abstract}
Abstrak:
Tulisan ini menelaah secara kritis tentang peran-peran sufisme dalam proses perubahan sosial di masyarakat, terutama di kalangan masyarakat perkotaan yang disimbolisasikan dengan kelas menengahnya. Unit yang diteliti adalah Majelis Shalawat Muhammad di bawah Mursyid Gus Kahar dan penerusnya Gus Mustakim. Meskipun sebagai representasi urban sufisme, fenomena Majelis ini tetap memiliki akar (benang merah) dengan sufisme klasik. Dalam menganalisis peran Majelis ini dalam perubahan sosial masyarakat menggunakan kerangka teori cultural broker dan cultural transetter Geertz dan Hirokosi sebagai perspektif. Hasil riset menunjukkan, secara simultan, konsisten, dan berkelanjutan, sufisme memiliki kontribusi besar dalam setiap perubahan sosial masyarakat terhadap nilai maupun ideologi dari luar. Sistem nilai yang inheren dalam sufisme yang disimbolisasi melalui guru/mursyid, ternyata tidak hanya sekedar berperan sebagai cultural broker seperti teori Geertz. Lebih dari itu, para guru/mursyid ini
\end{abstract}


mau merubah nilai maupun ideologi dari luar itu berubah menjadi sistem tradisi dan budaya baru. Fenomena ini seperti peran kultural para kyai dalam proses Islamisasi di Indonesia masa lalu. Fenomena ini seperti teori cultural transetter Hirokosi.

Kata Kunci: Urban sufisme, Majelis Shalawat Muhammad, Perubahan Sosial, Cultural Broker dan Cultural Trendsetter

\section{Introduction}

Sufism as the core of Islamic teachings has actually been practiced totally by the Prophet Muhammad. Therefore, from generation to generation, Sufis try to emulate the life of the Prophet Muhammad. ${ }^{1}$ For Sufis, the Prophet Muhammad is a symbol of the simplicity of life, a true mystic, and the pinnacle of spiritual achievement. ${ }^{2}$ It is no exaggeration if Sufism, as a branch of science in Islam that emphasizes the esoteric dimension gained momentum in this contemporary era. In the post-Industrialism era, urban society began to seek for religious values (say: Islam) in response to their acute problems. On the one hand, it cannot avoid the presence of global capitalism that does not only offer a model of the World Economic Order, but also as an "ideology" promoting a life style characterized by a hedonistic and secular western cultures. In addition, it is also dominated by its ratio as its characteristic. When these two poles (global capitalism and ratio) are no longer able to give inner satisfaction to each individual of urban citizens, they seek and attempt to find a solution in Sufism.

In the contemporary context, Sufism is increasingly gaining a place in the hearts of society, especially among urban citizens. In big cities in Indonesia, the middle class society shows interest in Sufism teachings. Such phenomenon seems to be inseparable from the previous neo-

\footnotetext{
${ }^{1}$ Syofrianisda dan M. Arrafie Abduh, "Pengaruh Tasawuf alGhazali dalam Islam dan Kristen", Jurnal Ushuluddin 25, no. 1 (2017): 70.

${ }^{2}$ Syamsul Rijal dan Umiarso, "Syariah dan Tasuwuf: Pergulatan Integratif Kebenaran dalam Mencapai Tuhan," Jurnal Ushuluddin 25, no. 2 (2017): 131.
}

Sufism movement. Experts, like Howell, call it the urban Sufism phenomenon. ${ }^{3}$ Nurcholis Madjid is, for example, a neo-Sufism figure who manages to attract the urban middle class society's attention by establishing Paramadina Foundation, Jakarta. His era is considered as a new era of change from neo-Sufism to urban Sufism. Another evidence indicating the growing of their interest towards the Sufism is the emergence of various Quranic Conventions that put forward the esoteric dimension (Sufism) rather than the exoteric aspect (Sharia or fiqh), such as the Rasulullah Assembly led by Habib Mundzir al-Musawwa, Adz-Dzikra Assemly by Ustadz Arifin Ilham, Qalbu Management by Ustadz AA Gym, and Sadaqah Management by Ustadz Yusuf Mansyur respectively and many more. In addition, there are similar assemblies organizing theological-based spiritual activities, such as ESQ training initiated by Ary Ginadjar. In fact, apart from this Islamic-based religious passion, there are spiritual religious movements and behaviors such as Anand Khrisna and Brahma Kumaris, Lia Aminuddin and the Eden Community, and other

\footnotetext{
${ }^{3}$ Among Islamologists, Julia D. Howell is the most serious in paying attention to the phenomenon of urban sufism in big cities in Indonesia. Howell has written many articles about urban sufism. Calling among Howell's most important works is: Julia D. Howell \& Martin Van Bruinessen, Sufism and The Modern in Islam, I.B. TAURIS, London-New York, 1988. Also read: Julia D. Howell, Revitalised Sufism and the New Piety Movements in Islamic Southeast Asia, published as Chapter 18, 276 - 292, in the Routledge Handbook of Religions in Asia, edited by Bryan S. Turner and Oscar Salemink Routledge, Abingdon UK (2015), Julia D. Howell, "Sufism on the Silver Screen Indonesian in Islamic Televangelism," Journal of Indonesian Islam 02, no. 02, (2008): 225-239.
} 
religious communities. ${ }^{4}$

Basically, Sufism has only developed among rural society. In line with the spiritual needs of the urban middle class society, it is gradually manifested in an institutionalized orthodox Sufism (Red: tarekat) or noninstitutionalized Sufism (say: Shalawat Assembly). ${ }^{5}$ Besides the Shalawat Muhammad Assembly led by Habib Mundir al-Musawwa in Jakarta, some other assemblies come to the ground such as Shalawat Muhammad Assembly led by Gus Kahar in Surabaya and Shalawat Adlimiyah Assembly led by Gus Mustakim in Bojonegoro as the objects in this study. One more example is the Shalawat Wahidiyah assembly led by Gus Abdul Madjid (Gus Majid), Kedung lo, Kediri. There are, indeed, many other Shalawat assemblies all over the cities in Indonesia. Various tarekats which were initially dominated by followers based in the country side have begun to shift their influence to penetrate the big cities in Indonesia. In its development, the urban Sufism phenomenon is inseparable from the conventional Sufism movement which is tied to the tarekat organizations such as the Qodiriyah Wa Naqsyabandiyah (TQN), Syadziliyah, Sattariyah, and many more. Surprisingly, there are about 158 assemblies affiliated with such conventional tarekat in Jakarta. ${ }^{6}$

Although both are interpreted as urban Sufism phenomena, however, urban Sufism from the orthodox line is different from the neo-Sufism line. The urban Sufism following the tradition of tarekat and various Shalawat Assemblies, for example, is characterized by its strong bond with the tarekat leaders and the Shalawat assemblies.

${ }^{4}$ Julia D. Howell, Pluralist Current and Counter Currents in The Indonesian Mass Media: The case of Anand Khrisna, in Religious Pluralism, State and Society in Asia (New York: 2014), 217.

${ }^{5}$ Zamakhsyari Dhofier, Tradisi Pesantren: Studi Pandangan Hidup Kyai dan Visinya Mengenai Masa Depan Indonesia, Edisi Revisi (Jakarta: LP3ES, 2011), 212-213.

${ }^{6}$ Oman Fathurahman, "Urban Sufism: Perubahan dan Kesinambungan Ajaran Tasawuf," in Gerakan dan Pemikiran Islam Indonesia Kontemporer, Rizal Sukma \& Clara Joewono (Eds.) (Jakarta: CSIS, 2007), 123-128.
This bond has been inherited from generation to generation in the teachings of orthodox Sufism. Here, a Mursyid or teacher becomes a central figure who is honoured or even adored. ${ }^{7}$ In addition, the existence of hierarchy and bai'at for each student is commonly known in the tradition of orthodox Sufism. In contrast, the urban Sufism deliberately negates the rituals of tarekat, hierarchical, and bai'at styles which they consider adoring the murshid. Therefore, the urban Sufism from the neo-Sufism line is not bound to certain tarekat and the motto it holds firmly is rational Sufism.

This article specifically focuses on the urban Sufism phenomena from the orthodox Sufism line, namely the Shalawat Muhammad assembly under Gus Kahar as the Murshid in Surabaya and Shalawat Adlimiyah assembly led by Gus Mustakim as the Murshid in Bojonegoro. These two names have actually been inseparable from each other. Both Gus Kahar and Gus Mustakim have actually practiced Shalawat Muhammad and Shalawat Adlimiyah. Both Shalawat come from the same teacher, KH. Muhammad Tamyiz, Pesapen, Surabaya. Besides these two, there is one more Shalawat known as Shalawat Kubro. It was initially led by Gus Syamsu Dhuha as the Murshid who was also a student of KH. Muhammad Tamyiz. However, he passed away in 2003. Gus Kahar himself is his student and successor, while Gus Mustakim is a student of both Gus Syamsu Dhuha and Gus Kahar and has continued their teachings.

In addition, the article which is based on the urban Sufism in the Shalawat Muhammad assembly aims at examining Naisbitt's thesis; High Tech High Touch. ${ }^{8}$ It is perceived the higher the technology is developing (high tech), the

\footnotetext{
${ }^{7}$ The basis of the references in the doctrine and the teachings of Sufism, especially concerning the relationship between the murshid / teacher and the students listed in the book of works Imam al-Ghazali, Ya Ayyuha al-Walad (Jakarta: al-Haramain Jaya Indonesia, 2005).

${ }^{8}$ John Naisbitt, High Tech, High Touch: Technology and Our Search for Meaning (New York: Broadway, 1999).
} 
more the human need spirituality (high touch). For this reason, the presence of spirituality itself becomes urgent and significant in explaining the presence of Sufism. To prove this thesis, the study applies the theory of Clifford Geertz, known as Cultural Broker and that of Hirokosi, which is famous for Cultural Trendsetter. In the context of orthodox Sufism, a murshid or teacher plays a significant role. Both theories strongly confirm the legitimacy of kyai (say: murshid or teacher in the terminology of Sufism) in social change comes from the doctrine of Sufism. Therefore, the role of urban Sufism in the today's urban society has a strong connection (sanad) with the traditions of the teachers in the past, which have continued to this day.

\section{From Pragmatic Escapism to Spirituality}

Based on the previous description, the phenomenon of spirituality (say: Sufism) always attracts the experts' attention. One of the spirituality masters, Naisbitt, for example, says in High Tech High Touch that the technological advances have made modern humans become giddy. When the technology is adored and the mainstreaming of logic and rationality is increasingly dominant, it would cause them to lose their faith. In the Mega Trend 2000, Naisbitt has even constructed more interesting thesis. According to him, the adherents of an organized and formal religion will experience a setback, whereas a religion that prioritizes spirituality will increase. In this thesis, he emphasizes, 'spirituality yes, organized religion, no'. Essentially, it is used to read the 21 st century phenomena marked by the revival of religion that strengthens spirituality, instead of organized religion. ${ }^{9}$ At the same time, it declares the fall of the rationality (reason) dominance in religion and other profane dimensions. No matter how rational human reasoning develops, he adds, it will never be able to defeat God's power. Here,

${ }_{9}^{9}$ John Naisbitt dan Patricia Aburdene, Megatrends 2000: New Directions for Tomorrow (London, Siddwick \& Jackson, 1990), 3. a demarcation line between science describing physical aspects and religious knowledge illustrating spirituality is clearly seen. ${ }^{10}$

Modern civilization has brought anxiety to the urban middle class society. Such anxiety is caused by the existence of a mechanical life pattern that puts humans like robots and machines. ${ }^{11}$ Consequently, they do not have a place to express and articulate their desires. Any forms of life anxiety are marked by two types of escape, alienation and suicide. The crisis is shown by the increasing number of people who have experienced anxiety, restlessness, and existential emptiness. Accordingly, it can create spiritual diseases that lead to stress, frustration, and the decline of human dignity and threaten human existence itself. Some spirituality experts attempt to offer values related to the spiritual dimension known as the dimension of Sufism in Islam. ${ }^{12}$

This phenomenon is marked by the birth of a new spirituality passion in various major cities in the world. It proves that the teachings of Sufism are again in demand by various levels of society who are seeking for existential identities. In addition, it also forms a wave coming from some of the major cities in the world, especially the big cities in Indonesia. In the Indonesian context, Budhy Munawar Rachman denies such phenomenon as "Sufism fever," which is the antithesis of religious tendencies that put forward a more fiqh approach. ${ }^{13}$ However, according to Ewert Cousins, Sufism is one of the typical

\footnotetext{
${ }^{10}$ Amsal Bakhtiar, "Agama Dalam Pandangan Futurolog," Kanz Philosphia: A Journal for Islamic Philosophy and Mysticism 3, no. 1 (2012): 59-75.

${ }^{11}$ Muhammad Anis, " Spiritualitas di Tengah Modernitas Perkotaan", Jurnal Bayan 2, no. 4 (2013): 1-15.

${ }^{12}$ Fredrich Schumacher in his book, A Guide for the Perplexed (1981: 8-12) says that so far people have only realized that all crises - both economic, fuel, food, environmental and health crises - depart from a spiritual crisis and self-recognition crisis we are against the Almighty. Schumacher's opinion is fully supported by Sukidi in his book, The Secret of Success in Happy Life: Spiritual In telligence (Jakarta: Gramedia Main Library, 2004), 4.

${ }^{13}$ Budhy Munawar-Rachman, "Spiritualitas: Pendekatan Baru dalam Beragama," dalam Komaruddin Hidayat (et.al), Agama di Tengah Kemelut (Jakarta: Mediacita, 2001), 48.
} 
phenomena of the latter part of the 20th century, just before the 21 st century. Here, the spirituality is again in demand to deal with most of the problems caused by modernity. In fact, spiritual teachers from the East who came to the West are able to answer the deep spiritual longings of many Westerns. Since then, publications about wisdom spirituality have begun to emerge. ${ }^{14}$

The existence of Sufism in the urban society is like the 'new religious movement' ${ }^{15}$ This happens because they can express a new meaning to the religiosity after being directly involved in Sufism spirituality. In the midst of career struggles, office activities, hunting for materials and various forms of power contestation and other economic access, they almost do not have special time to contemplate their God. On the other hand, religion in the realm of exoteric doctrine (Sharia/ Fiqh) which is black and white is unable to give inner satisfaction to every individual. Therefore, religiosity in the sense of Sufism is more important than scriptural religious experience as they and the others can directly feel its effect. For this reason, at the most common level, the existence of the new religion movement directs the meaning of Sufism and narrows it down as a solution to any problems. ${ }^{16}$

This is where various spirituality movements in various major cities in Indonesia arise and the flourish. The happening of various taklim (learning Islam) assemblies, tarekat, Shalawat assemblies, and study groups studying the dimensions of esoteric Islam (Sufism) is analyzed as a "new religion". Such phenomenon in major cities such as Jakarta, Bandung, Surabaya, Semarang, and other cities in Indonesia has a high response from the public, especially the upper

\footnotetext{
${ }^{14}$ Ewert Cousins, Hakikat Keyakinan dan Spiritualitas dalam Dialog Antaragama, dalam Ali Noer Zaman (ed), Agama untuk Manusia, terj. Ali Noer Zaman (Yogyakarta: Pustaka Pelajar, 2000), 77.

${ }^{15}$ Wasito Raharjo Jati, "Sufisme Urban di Perkotaan: Konstruksi Keimanan Baru Kelas Menengah Muslim," Jurnal Kajian dan Pengembangan Management Dakwah 05, no. 02 (2015): 177. ${ }^{16}$ Ibid., 178.
}

middle class society. This objectively confirms that the identity crisis of modern society has also struck among the middle and upper classes in big cities in Indonesia.

The spirituality movements in various big cities in Indonesia originally derive from the awareness of the urban community from the neo-modernist back ground. In the meantime, the spiritual movements of the orthodox group (say: tarekat) actually continues to expand in various urban centers in Indonesia although their initial existence cannot be negated. However, the tarekat is mostly considered as an 'underground movement' which is less exposed in academic discourse. It is not surprising that figures such as Nurcholis Madjid as a symbol of neo-modernists began to initiate a study forum under the Paramadina Foundation, which is more consensual in the Sufism doctrine than legal-formal doctrine (fiqh). His movement recognizably has a strong resonance. Various Taklim assemblies have begun to flourish in Jakarta and other major cities in Indonesia.

The phenomenon of assemblies started by Ustadz Arifin Ilham, AA gym, Ustadz Haryono, Mama Dede, and many others is a direct side effect of spiritual passion initiated by Naurcholis Madjid (also known as Cak Nur). Since then, spirituality has increasingly got a place in the hearts of urban society in various big cities in Indonesia. The rise of the spirituality started by the aforementioned neo-modernists, according to Julia D. Howell, is called urban Sufism. ${ }^{17}$ In parallel, the orthodox Sufism is also welcomed by the urban society. Essentially, the second Sufism is identified through its institutionalization of teachings, both through the tarekat itself and the Shalawat assembly. Therefore, behind the dynamics of the growing urban Sufism movements in urban areas, such movements are substantially classified into

\footnotetext{
${ }^{17}$ Julia D. Howell, "Introduction: Sufism and Neo Sufisme To Day in Indonesia," Review of Indonesian and Malaysian Affairs 46, no. 2 (2012): 1-24.
} 
two types; first, a neo-modernism-patterned urban Sufism, which is born and becomes an integral part of the neo-modernists; second, urban Sufism which has always been the identity of its original birth disseminated by the Sunni orthodox. To distinguish these two, one of them is characterized by strong bond in teacher-student relation such as the inherent tradition in general tarekat. ${ }^{18}$

As a part of the urban Sufism phenomena, the thing that distinguishes the figures of Gus Kahar and Gus Mustakim and the institutions of the Shalawat Muhammad assemblies in this study with other urban Sufism lies in their approach. Here, the two main figures represent the orthodox Sufism approach which is certainly different from the one used by Nurcholis Madjid, A Agym, Ustadz Arifin Ilham, and others with their respective study groups. Typically, the characteristics of orthodox Sufism include a strong bond with the murshid or teacher and institutionalization in terms of tarekat and Shalawat assembly. This strong bond is first marked by the emergence of 'feeling' and such feeling is then institutionalized in the term of a tarekat order or Shalawat assembly where the teacher and student form their bond in practicing dhikr and practices. ${ }^{19}$ The murshid/teacher has a key role to guide his followers. There are many tarekat and Shalawat assemblies, both of which emphasize the recognition of the Murshid figure. In number, there are many tarekats, such Qadiriyah, Syattariyah, Khalidiyah, Tijaniyah, Wahidiyah, and Naqsyabandiyah. Similarly, the number of Shalawat assemblies is also numerous. For the followers, Dhikr, wirid, and other practices they routinely read and internalize bring every individual to remember Allah, supposedly to keep remembering Him, so that their problem

\footnotetext{
${ }^{18}$ Rubaidi, "Reorientasi ideology Urban Sufisme di Indonesia terhadap Relasi Guru dan Murid dalam Tradisi Generik Sufisme pada Majelis Shalawat Muhammad di Surabaya," Jurnal Teosofi 5, no. 2 (2015): 298-300.

${ }^{19}$ Suwardi Endraswara, Mistik Kejawen: Sinkretisme, Simbolisme, dan Sufisme dalam Budaya Spiritual Jawa (Yogyakarta: Narasi, 2006), 62-63.
}

will be solved. This is what mostly happens among many tarekats. The unification of Tarekat Qadiriyah and Naqsabandiyah is due to their similarity in emphasizing the $d h i k r$ as a practice capable of becoming a 'cure' for its followers. ${ }^{20}$

The above theoretical description is the basis of argument in analyzing the phenomenon of Shalawat Muhammad assemblies, both in the Gus Kahar's era in Surabaya and his successor, Gus Mustakim, in Bojonegoro who has been alive until today. ${ }^{21}$ Thousands of Shalawat Muhammad followers with a 'home base' in 2 (two) cities in East Java, although coming from different social stratifications, are urban middle class society. This class is then again classified by their type of work and career such as Kyai, Gus, government employees, company managers, lecturers, doctors, bankers, politicians, bureaucrats, Indonesian National Police/Indonesian army, entrepreneurs, and lecturers including professor. In addition, some of them are middle-lower societies such factory employees, laborers, and farmers.

According to the observation, the phenomenon of Shalawat Muhammad Assembly is like various other urban Sufism institutions. Like a Super Market, this institution offers a variety of products offered to customers. Every urban citizen can choose and sort out the Super Markets that attract their attention as customers to various products offered. In this context, referring to Weber's term, they have their own rational choice for the actions they have taken and joining the Muhammad

\footnotetext{
${ }^{20}$ Shodiqil Hafil, "Studi atas Zikir Tarekat Masyarakat Urban Jemaah Thariqah Qadiriyah Naqshabandiyah di Jakarta," Jurnal Maraji 1, no. 1 (2014): 36: 56.

${ }^{21}$ In addition to being centered in Pesapen, Surabaya, as the beginning of the dissemination of the teacher's Shalawat Kubro (KH. Muhammad Tamyiz and Gus Symasu Dhuha), Gus Kahar opened like a branch of the Majelis Shalawat Muhammad in the residential area of Puri Indah, Sidoarjo. In fact, Gus Kahar spread Muhammad's Prayer in large Islamic boarding schools such as Darul Ulum, Rejoso, Jombang, Den Anyar, Jombang, Mojosari, Mojokerto, even to the Genggong Islamic Boarding School, Pajarakan, Probolinggo. These various Islamic boarding schools are like Branches of the parent of the Shalawat Muhammad center in Surabaya.
} 
Shalawat assembly. ${ }^{22}$ Such choice is influenced by inter-subjective and intra-subjective factors. Inter-subjective factor, for example, focuses on individual awareness of his/her own choice. In the meantime, the latter factor is more influenced by external factors such as the actors within the institution (Shalawat Muhammad assembly). The basis of this social action views humans as individuals who are actively involved in social life.

Another interesting social fact from various middle class followers in the Shalawat Muhammad assembly is precisely seen from the background of Islamic organization ideology. Besides mostly coming from a traditionalist group (say: NU/ Nahdlatul Ulama), some of the followers are modernists such as Muhammadiyah, Salafi, FPI, PKS, and even NII. Amin Thohari, for instance is a student who is relatively 'close' to Gus Kahar. $\mathrm{He}$ is a manager at a private company in Gresik, East Java. Aside from being a manager, he is also involved in an organization as the under bow of Muhammadiyah, East Java. He argues one of the rational choices he has become an active follower in the Shalawat Muhammad Assembly is spiritual reason, an empty heart that he felt for years as a citizen in Sidoarjo. ${ }^{23}$ As a member of the urban middle class society, he receives a spiritual answer from the figure of Gus Kahar. According to him, besides having unlimited thoughts in answering Islamic spirituality, he has a soo thing religious opinions for all groups.

A spiritual crisis also happens to Muhammad Rofi'i. Like Amin, he grew up in the tradition of a strong and strict modernist movement. Before becoming one of Gus Kahar's closest friends, he worked as a director of the IndonesianAmerican Friendship Foundation (YPIA/Yayasan Persahabatan Indonesia-Amerika) in the 1990s. According to his confession, he experienced a

\footnotetext{
${ }^{22}$ Goerge Ritzer, Sosiologi Ilmu Pengetahuan Berparadigma Ganda (Jakarta: Rajawali Press, 2004), 89-91.

${ }^{23}$ Wawancara dengan Amin Thohari, di Perumahan Puri Indah, Blok AG, nomor 12, Sidoarjo, tanggal 12 September 2017.
}

crisis of spirituality for many years. In an intersubjective context, he argues social structure in term of thought which is institutionalized in modernist organizations is the only single truth. "I am allergic to the name of kyai, including Gus Dur", he adds. ${ }^{24}$ In rational choice, his construction of thought has slowly changed after encountering intra-subjective context symbolized and illustrated by Gus Kahar. Feelings of harmony, as mentioned in Naisbitt's thesis on High-Tech High-Touch, for modern urban society are not only interpreted in industry and technology aspect. The styles of thinking which tend to be positivistic (black and white) and its implications also happen when interpreting religion. In his view, he emphasizes the spirituality of Shalawat Muhammad eliminates the barriers of Islamic primordialism based on Islamic organization. ${ }^{25}$ As a consequence to this paradigm, he always thinks positively in seeing individuals without the restrictions by religious organizations.

$\mathrm{SF}$ is another example of the Shalawat Muhammad followers who has experienced significant social changes, especially in Islamic perspective. Before routinely joining the Shalawat Muhammad assembly led by Gus Kahar, this woman was actively involved in a banned organization, the Negara Islam Indonesia (NII). The hard doctrine of NII in the subconsciousness forms a strong attitude and thought in herself. "According to the NII, hand-shaking is not permissible for men and women. For groups opposing NII, even killing is justified", she explains. ${ }^{26}$ The affection, kinship and humble attitudes shown by Gus Kahar to every congregation and guest, according to her, turn out to make her aware of the true meaning of Islam. In turn, besides shown by the real behavior

\footnotetext{
${ }^{24}$ Wawancara dengan Muhammad Rofi'i, mantan Direktur Yayasan Persahabatan Indonesia-Amerika (YPIA), di Perum Puri Indah, Blok AG, nomor 11, Sidoarjo, tanggal 12 September 2017. ${ }^{25}$ Rubaidi, 309.

${ }^{26}$ Wawancara dengan SF dalam suatu kesempatan Pengajian Majelis Shalawat Muhammad Gus Kahar, di Perum Puri Indah Blok. AG/12, Sidoarjo, tanggal 23 Juli 2015.
} 
of Gus Kahar and the spark of his thought, the meaning of Islam as rahmatan li al- 'alamin (the blessing for the whole world) presented in various Shalawat Muhammad assemblies totally change her mindset which was typical to NII.

The character of positivistic, mechanical, and black and white thoughts referring to the structure of the logic of modernism, in fact, does not only form the structure of thinking of the modern middle class society, but also influences their way of thinking and understanding religion (Islam). Such structure is reinforced by jurisprudential reasoning pattern that tends to be black and white; halal versus haram; Muslim versus heathen, and so on. This pattern contributes greatly to the way urban society practices their religion which is away from the spirituality values. ${ }^{27}$ For this reason, Komaruddin Hidayat mentions at least four perspectives on why Sufism is growing in big cities. First, it is in demand by the urban society a means of seeking for the meaning of life. Second, it is a means of struggle and intellectual enlightenment. Third, it is a means of psychological therapy. Fourth, it is a means to catch up with the trend and development of religious discourse. ${ }^{28}$

The above facts describe the existence of the Shalawat Muhammad assembly developed by Gus Mustakim in the midst of community in the city of Bojonegoro, East Java in the initial period. He relates that an established socio-religious structure tends to reject any groups and new teachings that are willing to change the system and social-religious order. ${ }^{29}$ Therefore, he adds, many kyai question the existence of the teachings of Shalawat Muhammad assembly. In fact, some of the kyai do not hesitate to address and declare the assembly as a form of heresy. After knowing

\footnotetext{
${ }^{27}$ Nurcholis Madjid, "Tasawuf sebagai Inti Keberagamaan," Jurnal Pesantren II, no. 3 (1985): 3.

${ }^{28}$ Oman Fathurahman, Urban Sufism: Perubahan dan Kesinambungan Ajaran Tasawuf, http://naskahkuno.blogspot. com/, 17 September 2017.

${ }^{29}$ Wawancara dengan Gus Mustakim, di rumahnya, J1. A. Yani, nomor 2, Bojonegoro, hari sabtu, tanggal 19 Agustus 2017.
}

the chain of the Shalawat Muhammad teachers, starting from KH. Abdurrahman Wahid (Gus Dur), KH. Hamim Jazuli (Gus Mik), KH. Romli Tamim, KH. Hasyim Asy'ari, and Syaekhona Cholil, they have finally accepted it. Similarly, each individual of the kyai has finally accepted it and even understand its teachings as it does have the sanad (chain) of teachings and the source of teachings passed from a Sufi teacher to another Sufi teacher until it is connected to Prophet Muhammad. ${ }^{30}$

In addition seeking for the meaning of truth through Islamic spirituality as exemplified in some of the above case studies, it cannot be denied that rational action of every urban middle class individual determines the choice of Sufism institutions based on certain motives. The motives range from stress medication, economic improvement, problem solving, inner peace seeking, to the actual search for the true meaning of Islam. Therefore, the motives of every urban Sufism institution with followers consisting of different social layers of urban middle class society are not far from the aforementioned motives, including the Shalawat Muhammad Assembly itself. In the treasures of tarekat and pesantren adopted from the teachings of Sufism, a term called barakah is commonly known. The meaning of barakah is a value which is useful in the life of students for their dedication to a murshid or teacher in the tradition of Sufism. In the context of the Shalawat Muhammad assembly, both Gus Kahar and Gus Mustakim know exactly the motives of each individual follower. According to them, the true motive of Sufism is none other than seeking for the essential meaning of Islam itself. The seeking here, Gus Kahar says, is to find the existence of God, not others.

Various motives of each urban middle class individual towards the urban Sufism institutions, especially in the context of Shalawat Muhammad

\footnotetext{
${ }^{30}$ Wawancara dengan Gus Kahar, di Komplek Perumahan Rizwood, Pakuwon City, Surabaya, tanggal 23 Juli 2015.
} 
assembly, can be identified to what extent the level of their closeness with Gus Kahar and Gus Mustakim. The followers in the assembly naturally forma social lining like a spiral. The social lining here is the presence of public followers, special followers and the inner circle. The public followers, for example, usually come to every Shalawat Muhammad Assembly without having to meet or shake hands with the murshid. Meanwhile, the special followers consist of individuals who faithfully listen to the Shalawat recited by Gus Kahar and Gus Mustakim for hours in a form similar to open house. ${ }^{31}$ Lastly, the members of the inner circle are special students who do not only come for the assembly, but also on other occasions outside the assembly. The followers who form this inner circle usually understand more deeply the broad spectrum of Sufism thinking and the khaliyah (existence) of the murshid.

The phenomenon happening to the urban middle class society who takes part in urban Sufism of Shalawat Muhammad assembly is believed to be different from the same middle class in the urban Sufism form the neo-Sufism line. The circle of special followers and the inner circle, for instance, are bound by the teacher-student relationship without reserve. The Sufism involvement here is no longer affected by economic motives, family problems, stress, or others. At the very least, they have gone beyond various phases. The only remaining motive is total devotion to the murshid to be educated as the murshid was once also educated by his teachers. The disciples or students who make the inner circle are taught various certain degrees of secret

\footnotetext{
${ }^{31}$ In the author's observation, in each of the Shalawat Muhammad assemblies which were attended by Gus Kahar and Gus Mustakim, after reading the aurat of Shalawat Muhammad which contained dhikr, wirid, and prayers, followed by an open house led directly by both. This session takes place after jama'ah generally return to their homes. This open house lasts late at night before morning until 2:00 a.m. In this open house, pilgrims are free to ask what ever matters related to religious matters to career issues, even individual problems.
}

knowledge (sirri). In the terminology of Sufism, the secret knowledge is known as makrifat and hakikat. H. Muhammad Sukri is one of the students in Gus Kahar's inner circle who works as a cigarette entrepreneur. ${ }^{32}$ According to him, before becoming his student, approximately 2 (two) years before meeting him, he heard that Gus Kahar once told other followers that he would be his student. At the time of the first meeting, he adds, the cigarette business he was involved in had a serious problem. After actively participating in the Shalawat Muhammad Assembly, the cigarette business has gradually returned to normal. At that moment, he has begun to learn various essences about the teachings of Sufism.

The above description illustrates the roles of social transformation on the process of change shown by urban Sufism institutions. It also emphasizes the dimension of Sufism is proven from time to time to having always played a social change in society. One thing for sure is the flexibility of Sufism teachings in transforming the social change, especially in the context of urban-based modern society in the late 20th century and the beginning of the 21 st century. The fundamental reason regarding the role of Sufism for urban middle class society is that this class is experiencing acute psychological problems in the era of High Touch High Techas illustrated in Naisbitt's thesis. Like the role of Sufism in the 21 st century, the same role was seen in the 18 th century. In the late 18 th century, tarekat teachers began to enter rural areas from coastal cities. They built pesantren and taught farmers pragmatic Islam. This century is considered as a fundamental Islamization process as Islam appeared to fill the cultural vacuum due to the fall of local Hindu kingdoms and the powerful penetration by the Dutch. ${ }^{33}$ Further, the 19th

\footnotetext{
${ }^{32}$ Wawancara dengan H. Muhammad Sukri, seorang pengusaha rokok, di kediamannya, Desa Sentul, Tanggul Angin, Sidoarjo, tanggal 10 September 2017.

${ }^{33}$ Moeslim Abdurrahman, "Kesyahduan Sufi dalam Transformasi Sosial: Suatu Pengamatan Perkembangan Tarekat," Jurnal Pesantren II, no. 3 (1985): 49.
} 
century is also described as a period in which the tarekat took a very important political role. West Java, especially in Banten, Tasikmalaya and Garut, apart from becoming the base for tarekat teachings, also became the base of the farmers uprising against the Dutch. Suffice to say, the Sufism spirituality seems to have never been vacant in the history of Indonesia's movement, ranging from the Diponegoro war, the independence war, to the birth of Jihad resolution on October 22 followed by the war of November $10,1945$.

\section{Mursyid as a Cultural Broker \& Cultural Trendsetter}

Although it is not linear, the phenomenon of urban Sufism institutions in various cities in Indonesia are classified into 2 (two) main sources; First, urban Sufism which has a common connection with the tradition and teachings of Sufism deriving from the line of Sunni orthodox. Such Sufism is easily identified in the form of Rasulullah assembly, Shalawat assembly, and its existence of old institution, tarekat. Another common identification is the emphasis on irrational relationships between murshid/teachers and their disciples/students (followers). ${ }^{34}$ In addition, the baraka dimension is the main point of reference. The constructed thesis here is that a murshid has a close relationship without a hijab (boundary) with al-Haq (God). The science of makrifat, according to orthodox Sufism, becomes a guarantee for the social system that ties this relational relationship. It will eventually result in submission without reserve. Personally, the source of this orthodox Sufism refers to Sufi figures such as al-Ghazali and Junaid al-Baghdadi, as well as major Sufi

\footnotetext{
${ }^{34}$ The meaning of "irrational" does not mean without foundation. The fundamentals of the teacher-student relational pattern are based on the book ayyuha al-Walad by al-Ghazali or taklim alMuta'allim, the work of al-Jarnuzi. The spiritual basis of this relationship is because of a belief, that, a murshid is an alim, allamah, even a guardian who no longer has a hijab (boundary) with the Khaliq. See: Rubaidi, 309.
}

saints such as al-Bagdadi, al-Misri, al-Jaelani, al-'Arabi, al-Jilli, Hallaj al-Mansur, al-Syibli, al- Rumi, and many more. These Sufi teachers form a circle with each other. For example, Ibn al-'Arabi had studied al-Ghazali's thoughts. On the contrary, al-Ghazali also studied al-Misri, al-Bagdadi, and so on. ${ }^{35}$ And so on, other Sufi teachers at any time.

Second, urban Sufism which is originated from the 19th century's neo-Sufism line. In addition to claiming to refer to al-Ghazali sufism, another source tells that this Sufism is based on the thought of Ibn Taymiyyah. Fazlurrahman is the first figure to conceptualize this neo-Sufism in which its rationale is the teachings of Sufism adjusted to the Sharia and fiqh on the one hand, and adapted to the life of modern society on another. ${ }^{36}$ In addition to the above rationale, another basis is the various sources of modernist opposition to Sufism in the 18th century. Some points of modernist rejection of Sufism include the concept of tarekat, zuhud, taklid (blind following), and adoration of murshid or teachers. These conceptions have all led to bid'ah (innovation) and khurafat (superstitions). Therefore, various urban institutions in the neo-Sufism are relatively different and easily characterized from urban Sufism of the orthodox line both in terms of institutional aspect and teachings. Apart from the different sources, the birth of urban Sufism institutions opens up new discourses about the treasures of Sufism in Indonesia. In the Indonesian context, Nurcholis Madjid as an icon of reformers who comes from the pesantren tradition has a big contribution to initiating urban Sufism. ${ }^{37}$

The theoretical framework of the cultural broker by Cliffort Geertz and the cultural tradition by Hirokoshi explains the phenomenon of urban Sufism in term of Shalawat Muhammad assembly

\footnotetext{
${ }^{35}$ Syofrianisda dan M. Arrafie Abduh, 74-75.

${ }^{36} J u l i a$ D. Howell, "Introduction: Sufism and Neo-Sufism in Indonesia today," Review of Indonesian and Malaysian Affairs 46, no. 2 (2012): 1-24.

${ }^{37}$ Julia D. Howell, "Sufism and the Indonesian Islamic Revival," The Journal of Asi an Studies 60, no. 3 (2012): 701-729.
} 
as part of the urban Sufism in the orthodox line. Both theories emphasize the socio-cultural roles of kyai (murshid/teacher) among society. They have long been used in analyzing the role of kyai on socio-cultural changes in the society. Geertz and Hirokoshi's analysis is based on two districts that reflect rural society. However, it can be used in reading the symptoms of change in the context of urban society though. Geertz, for instance, conducted his research in Mojokuto (say: Pare, Kediri), Hirokoshi finished it in Garut, West Java, precisely in the Cipari Islamic boarding school, Ajengan Yusuf Tojiri.

Broadly speaking, Geertz's thesis states the kyai acts as the filter of information that enters the santri environment, transmits what is considered useful and discards what is deemed harmful to them. However, he adds, such role will be stuck when the flow of incoming information is very heavy and the kyai can no longer filter it. In such circumstances, the kyai will lose its role and experience a cultural gap (cultural lag) with the surrounding community. ${ }^{38}$ His conclusion is denied by Hirokoshi who says his findings are not all right. He mentions the kiai does not play a passive role as a broker as stated by Geertz. The kiai actually play an active role in selecting the positive values and attitudes that the community should develop. As such, they participate in formulating their own priority scales for social change and developing their pioneers on the ongoing process of change. Thus, Horikoshi confirms, it doesn't mean that the kiai does not play a role at all, but it delays the coming of change through the process of filtering information. In addition, he fully plays a role as he understands that social change is an inevitable development. The problem he faces is if the way to change can be completed without destroying the existing social bond, but rather utilizing the

${ }^{38}$ Clifford Geertz, "The Javanese Kyai: The Changing Role of a Cultural Broker," Comparatif Studies in Society and History 2, no. 2 (1960): 228-249. bond as a desired mechanism of social change. ${ }^{39}$

According to Geertz and Hirokoshi, the basic capital of kyai in playing their role on this cultural change is the teachings of Ahlussunnah wa al-Jama'ah (Aswaja). Organizationally, the teachings are followed by the kyai from the NU traditionalist group. The religious view that differs between the NU traditionalist group and the modernists lies in the way of interpreting the texts (Qur'an \& Hadith) when they are faced with socio-cultural realities. The modernists, for example, tend to be closed-minded by basing their arguments on the intellectual understanding on the message of revelation (Qur'an-Hadith). Meanwhile, the kyai with traditionalist socioreligious backgrounds generally refer their arguments to the meaning of the context more freely, so that they tend to be flexible and open minded. ${ }^{40}$ More importantly, this traditionalists' way of thinking is based on the Sufism which is learned from the Sufi teachers in the NU environment.

Gus Kahar and Gus Mustakim represent the theories of Geertz and Hirokoshi in the Shalawat Muhammad assembly. These two figures are like magnetic fields. Every object on their side will be attracted by their magnetic field. Many of their followers come from educated middle class society like lecturers and even professors in Islam. In addition, some of them are even ruling class actors such as Gus and Kyai. However, when dealing with the horizons of thought with no limits in the dimensions of Islamic spirituality, they are like helpless. For this reason, the conscious choices made by the middle class of this segment including the ruling class, according to Weber's term, are called traditional rationality, the rationality which is fought for the traditional

\footnotetext{
${ }^{39}$ Hiroko Horikoshi, Kyai dan Perubahan Sosial (Jakarta: Pusat Pengembangan Pesantren dan Masyarakat (P3M), 1987), 232.

${ }^{40}$ Miftah Faridl, "Perilaku Sosial-Politik Kyai di Tengah Masyarakat Transisi: Kasus di Wilayah Cirebon dan Bandung," Jurnal Mimbar XXI, no. 2 (2005) : 171.
} 
values of the society life. ${ }^{41}$ In the context of the educ ated middle class, their admiration is based more on the depth of Gus Kahar and Gus Mustakim in explaining various dimensions of Islamic teachings. In Sufi terminology, this specialty refers to as mukhasafah, the opening of the hijab (boundary) between the dimensions of beings and their God.

The above description depicts the teacherstudent relationship in orthodox Sufism as happens in the Muhammad Assembly which is so strong and even adored. To agree or disagree, the positive value of the absolute teacher-student relationship facilitates the murshid/teacher in making social changes. Their authority as actors of change relies on their mastery of the dimensions of Islamic teachings comprehensively. In addition, their authority, especially in the terminology of Sufism is known as maqam wali and known to be close to Allah. In fact, according to the teachings of Wihd at al-Wujud (Unity of Existence) or in the conception of Java known as manunggaling kawulo-Gusti, the Al-Haq (God) and al-Khalq (beings) are inseparable. According to the interpretation of the fuqaha (jurists), both Gus Kahar and Gus Mustakim, qadla (the divine decree) and qadar (the predestination) can be changed by humans. "Your baby is a boy", said Gus Mustakim to one of the couples from his followers. "According to result of USG, it's a girl, Gus" answered the wife. "No, it's a boy, said Gus Mustakim again. "At birth, indeed he

\footnotetext{
${ }^{41}$ Anthony Giddens, Kapitalisme dan Teori Sosial Modern, terj. Soeheba (Jakarta: UI Press, 1986), 180-189.

${ }^{42} \mathrm{Man}$ is meant to be nothing but someone who has attained the station of dignity. In the conception of wihdat al-Wujud or manunggal ing kawula-Gusti, there is no longer an essential separatio $\mathrm{n}$ between al-Haq and al-Kalq, especially in the dimension s of spirit, that is, the soul in al-Khalq. In this dimension, the words of al-Khalq are nothing but the words of al-Haq. Therefore, in the famous Javanese philosophy with the jargon "sabdo pandhita ratu." This jargon only applies to the sayings of saints who are known as wali. In the Sufism discourse, this refers to the words of Siti Jenar; "There is no Siti Jenar, there is only God." See: R. Michael Feener, "A Examination of the place of al-Hallaj in the development of Souteast Asian Islam," KTILV-Journal, Bijdragen tot de Taal, Land-en Volkenkunde 154, no. 4 (1998): 576.
}

is a boy, but he acts like a girl. He should have been born as a girl", he adds while smiling. ${ }^{43}$ The same story happens to one of the women, who is the relative of Gus Kahar's teacher, Gus Syamsu. Her name is Lin Ling. She has confided in Gus Kahar and said that her husband wants a boy as 2 (two) of their children are girls. ${ }^{44}$ When he was in the process of delivering the baby, Gus Kahar took time to come. "Your baby is a boy, Ling", he said after a short visit and immediately came out. ${ }^{45}$ She could hardly believe it, especially after the baby was born and is male.

Such eschatological stories are a part of social transformation in both Prophet and saint figures in the tradition of Sufism. In psychological-spiritual aspect, these stories are important in convincing the followers. Sociologically, the events in the stories become cultural and symbolic evidences for the actors/agents, both in mediating sociocultural changes (cultural brokers) and even creating new cultures (cultural trendsetter). This sociological view is based on the logic of Sufism saying that qadla' and qadar is not the prerogative right of God, but can change through His saints whom He loves. Based on the Lin Ling's story, Gus Syamsu as Gus Kahar's teacher was quite angry when the baby was born a boy. Both of them then had conversations. "What did you do to that baby? It is predestined as a girl in the lauh al-Mahfudz", asked Gus Syamsu. "I did not do anything. I just asked and prayed to God", replied Gus Kahar. ${ }^{46}$

\footnotetext{
${ }^{43}$ Disampaikan dalam Pengajian Majelis Shalawat Muhammad di Rumahnya, Jl. A. Yani, nomor 02, Bojonegoro, Selasa, 23 Oktober 2017.

${ }^{44}$ During a lecture by the Shalawat Muhammad in the office of the company of Gusti Hartono, Cerme, Gresik, which was attended by Gus Kahar in 2015, coincidentally Lin Ling attended to Gus Kahar. During the recitation, the author had the opportunity to interview him. Medically, when an ultrasound in one hospital in Singapore is declared female.

${ }^{45}$ It was told directly by Gus Kahar together with the presence of Lin Ling at the recitation of the Majelis Shalawat Muhammad at the Office of Gusti Hartono, in Cerme, Gresik, at the beginning of 2015. ${ }^{46}$ It was told directly by Gus Kahar together with the presence of Lin Ling at the recitation of the Majelis Shalawat Muhammad at the Office of Gusti Hartono, in Cerme, Gresik, at the beginning of 2015 .
} 
The above specialty is social capital in carrying out socio-cultural transformation of society in the midst of the globalization flow. One of the examples is the concept of zuhud. In the standard concept, it has been always interpreted as simple life from time to time. This means staying away from the communal life (uzlah), living in poverty and alike. "Zuhud does not mean dressing in rags or living in the middle of a forest", said Gus Mustakim one day. ${ }^{47}$ "Having a rich life is also called zuhud. Driving a Mercedes-Benz like I do is also zuhud", said Gus Kahar. ${ }^{48}$ This reinterpretation is positively correlated for the urban middle class society, who is economically well-established in general. The essence of zuhud, according to Gus Kahar and Gus Mustakim and in the meaning of generic Sufism, is not a poor or simple life or a life far from the hustle and bustle of society. It does not correlate with all material attributes. Essentially, it means subordinating others, but God. Gus Kahar cites the words from one of the great Sufi teachers, Hasan al-Syadzili. Besides known as a Sufi teacher, he was also a wealthy merchant. However, this material wealth attribute did not make him forget his Lord.

Gus Kahar and Gus Mustakim's Sufism view, according to his followers, becomes a word view in seeing the modern world. All the hustle and bustle of modern life with all the developments in information technology, industrialization and various other variables of global capitalism has nothing to do with the monotheistic-Sufistic dimension. This view is in fact compatible with the view of the majority of Naqshabandiyah followers in Turkey. Mehmed Zahid, for example, argues that Muslim communities are allowed to work in industry applying the latest technology; they are even obliged to do it. ${ }^{49}$ In contrast, the

\footnotetext{
${ }^{47}$ Gus Mustakim said in the Recitation of Salat Muhammad at his residence, Jl. A. Yani, number 02, Bojonegoro, Tuesday, August 22, 2017.

${ }^{48}$ Rubaidi, 310.

${ }^{49}$ Sulaiman, "Perubahan Sosial berbasis Tasawuf: Studi Kasus Fethullah Gülen dan Gülen Movement," Al-Tahrir: Jurnal Pemikiran Islam 16, no. 1 (2016): 3.
}

scripturalists, besides forbidding the western ideology, do not hesitate to ban various products produced by the Western. Responding to these Western products, Gus Kahar has another view based on the teachings of monotheism. "Everything on this earth is for the believers. The Germans (say: heathens) create airplanes, but we, as the believers, take and enjoy them. Which one is better, creating or enjoying the airplanes?", he asked to his followers. ${ }^{50}$

Further, their thoughts in the Shalawat Muhammad assembly have a great deal of contribution to the process of social transformation for his followers. In the midst of static ways of thinking and placing Islam among the various world ideologies and cultures, the assembly offers an alternative breakthrough in bridging the choice of actions made by Muslims. Not only do their thoughts bridge their actions, but also give a new colour to every change initiated by the Western cultures under the value of monotheism. For a group of Muslims, the Western cultures are considered having negative impacts, but the followers of Shalawat Muhammad assembly say them differently. At the very least, the cultures are positioned as something neutral, depending on the point of view and the way to use them. This is where the role of Sufism means dealing with social change. Such role is very important to continue to dialogue on Sufism and at the same time refresh it in order to continue producing transformative power ${ }^{51}$ and constructive social criticism. ${ }^{52}$ The existence of karaoke entertainment (NAV, Happy Puppy, and alike), for example, is considered negative and even haram (forbidden) for most Muslims. As an entertainment industry that has become a popular culture among the urban middle class society, Gus Kahar presents a 'new colour in

\footnotetext{
${ }^{50}$ Dikutip dalam Pengajian Majelis Shalawat Muhammad Gus Kahar, di Perum Puri Indah, Blok. AG/12, Sidoarjo, April 2015. ${ }^{51}$ Abdul Kadir Riyadi, Antropologi Tasawuf: Wacana Manusia Spiritual dan Pengetahuan (Jakarta: LP3ES, 2014), 104. ${ }^{52}$ Said Aqil Siroj, Tasawuf sebagai Kritik Sosial: Mengedepankan Islam sebagai Inspirasi, Bukan Aspirasi (Bandung: Mizan, 2006), 132.
} 
utilizing this industry. Various poems or lyrics in songs depend on how we live up to them. "This song reminds me of Gus Syamsu," recalled Gus Kahar while singing the longing song composed by Mansyur S. and entitled "Setali Mata Uang" (a bunch of money). ${ }^{53}$ Singing is one of Gus Mustakim's hobbies. "Songs can quickly bring us to have a dialogue with God," said Gus Mustakim. "Make your mind happy, the fortune will then come to you," he adds, expressing happiness through songs. ${ }^{54}$

The above description also justifies the role of Shalawat Muhammad assembly in the process of social change. According to Hirokoshi, the roles of Kyai as a cultural trendsetter include; (1) The kyai do not play a role in reducing the changes that occur, but pioneering social changes with their own creativity, (2) They do not filter information, but offering an agenda of change they consider suitable with the real needs of the people they lead, and (3) They do not passively delay the coming of changes through information filtering process, but they play a full role..$^{55}$ They understand that social change is an inevitable development. In Weber's sense, the conscious acts or choices of Shalawat Muhammad assembly represented by Gus Kahar and Gus Mustakim offer value oriented rationality. ${ }^{56}$ Both figures do not only act as cultural brokers, but also give a new meaning to the culture which was previously justified as negative values by some Muslims. On the part of his followers, they see the value of new benefits for their lives.

According to Weber, an action is considered social and has meaning if an individual interacts with another and the result of their action affects their behaviour. ${ }^{57}$ His theory brings several key

\footnotetext{
${ }^{53}$ Quoted in the Recitation of the Shalawat Assembly of Muhammad Gus Kahar, at Perum Puri Indah, Blok. AG / 12, Sidoarjo, April 2015.

${ }^{54}$ Gus Mustakim said in the Recitation of Salat Muhammad at his residence, Jl. A. Yani, number 02, Bojonegoro, Tuesday, August 22, 2017.

${ }^{55}$ Hiroko Horikoshi, 232.

${ }^{56}$ Anthony Giddens, 180-189.

${ }^{57}$ H. P. Secher, Basic Concepts in Sociology, Contributors: Max Weber (New York: Citadel Press), 1962.
}

words (1) Actor/agent, action, and meaning. This is where the significance of the role of an actor or agent in social interaction lies in. He is able to bring social change in his community, and even his external community. ${ }^{58}$ Gus Kahar and Gus Mustakim, for instance, give every meaning of life with monotheistic (tauhid) values adapted to the popular culture of urban society. Hanging out at Cafe, Mall and other public places is adapted to the content of monotheism. Apart from the study in the Shalawat Muhammad assembly, they often invite certain students only to eat and drink or go shopping at shopping centers in Surabaya. However, what both talk about at the Cafe and Mallis various dimensions of essence and makrifat.

One of the prominent colours in various Shalawat Muhammad assemblies is the impression that this assembly is attended by a middle class or even upper class society. Such impression is seen from the motorcade of branded four-wheeled vehicles accompanying Gus Kahar's car heading to the house of one of his followers where the recitation of Shalawat Muhammad takes place. Gus Kahar himself has even kept changing his cars, ranging from Mercedes Benz E Class, the latest 2015's Mercedes Benz, CLS, Robicon, Mini Cooper, Velfire, Alphad, to Pajero Sport. In the meantime, a row of cars owned by his followers ranges from Mercedes Benz E Class, Mercedes Benz C Class, Pajero, Innova, and so on. ${ }^{59}$ In addition, the clothes Gus Kahar, Gus Mustakim, and their followers are also branded such as Rohul, Lacoste, Hugo Boss, Hugo Orange, Nautica, Zara, and many more as seen from the logos. During the Assembly, food and beverages are served like the ones at the parties. From here, the two murshid give a lesson or hint that the Sufism is always in line with the era. It is not stuck under the hedonic or profane culture. They even include the contents of monotheism in the assembly.

\footnotetext{
${ }^{58}$ Bryan S. Turner, Teori Sosial Dari Klasik sampai Postmodern (Yogyakarta: Pustaka Pelajar, 2012), 111.

${ }^{59}$ Rubaidi, 312.
} 


\section{Conclusion}

Sufism in the historical dimension has an important role on social change in the society and is in accordance with them. This view emphasizes that Sufism is not bound by time and place. When a religious doctrine which is understood exoterically shows a radical face, the intrinsic dimension of religion (Islam) identified as Sufism, on the contrary, is able to communicate with various social changes as an impact from the values and ideologies coming from the outside. Shalawat Muhammad assembly as part of the urban Sufism phenomena located in Surabaya and Bojonegoro, for instance, has proven the role of social change for the society, especially its followers.

The institutionalization of the teachings of Sufism under the doctrine of Shalawat Muhammad assembly through its two murshid, Gus Kahar and Gus Mustakim, attracts the attention of the urban middle class. In an in-depth study, the doctrine of urban Sufism in the Shalawat Muhammad assembly teaches tauhid (monotheism) as in other traditions of classical Sufism. The essence of the tawheed teachings actualized and demonstrated by Gus Kahar, Gus Mustakim and their followers is commendable behaviours shown to anything or anyone.

The ideological and praxis implication of institutionalizing the teachings of urban Sufism in the Shalawat Muhammad assembly is the formation of the students' thoughts and behaviour. Amidst the rapid social change in the context of urban middle society, Gus Kahar and Gus Mustakim's followers are not affected by the hustle and bustle of the change itself. Similarly, despite the turmoil of Islamic radicalism among the urban middle class society, they believe that Islam is a religion of peace and mercy and rahmatan li al-'alamin (the blessing for the whole world). While other Muslims clash with various symbols of secularism, capitalism, and the Western in general, they continue to accommodatively accept various values and ideological systems that come from them. This is where the theoretical perspective of cultural broker and cultural trendsetter by Geertz and Hirokosi is very helpful in understanding the thoughts and behaviour of urban middle class society as the members of the Shalawat Muhammad assembly.

\section{References}

Abdurrahman, Moeslim. "Kesyahduan Sufi dalam Transformasi Sosial: Suatu Pengamatan Perkembangan Tarekat". Jurnal Pesantren II, no 3 (1985).

Anis, Muhammad. "Spiritualitas di Tengah Modernitas Perkotaan." Jurnal Bayan 2, no. 4 (2013).

Bakhtiar, Amsal. "Agama Dalam Pandangan Futurolog." Kanz Philosphia: A Journal for Islamic Philosophy and Mysticism 3, no. 1 (2012).

Dhofier, Zamakhsyari. Tradisi Pesantren: Studi Pandangan Hidup Kyai dan Visinya Mengenai Masa Depan Indonesia. Edisi Revisi. Jakarta: LP3ES, 2011.

Endraswara, Suwardi. Mistik Kejawen: Sinkretisme, Simbolisme, dan Sufisme dalam Budaya Spiritual Jawa. Yogyakarta: Narasi, 2006.

Faridl, Miftah. "Perilaku Sosial-Politik Kyai di Tengah Masyarakat Transisi: Kasus di Wilayah Cirebon dan Bandung”. Jurnal Mimbar XXI, no. 2 (2005).

Fathurahman, Oman. "Urban Sufism: Perubahan dan Ke sinambungan Ajaran Tasawuf." Dalam Rizal Sukma \& Clara Joewono (Eds.). Gerakan dan Pemikiran Islam Indone sia Kontemporer. Jakarta: CSIS, 2007.

------. Urban Sufism: Perubahan dan Kesinambungan Ajaran Tasawuf, http:// 
naskahkuno.blogspot.com/, September $17,2017$.

Feener, Michael R. "A Re-Examanation of the place of al-Hallaj in the development of Souteast Asian Islam". KTILVJournal, Bijdragen tot de Taal, LandenVolkenkunde 154, no. 4 (1998).

Geertz, Clifford. "The Javanese Kyai: The Changing Role of a Cultural Broker." Dalam Comparatif Ewert Cousins, Hakikat Keyakinan dan Spiritualitas dalam Dialog Antaragama, dalam Ali Noer Zaman (ed). Agama untuk Manusia. Terjemahan Ali Noer Zaman. Yogyakarta: Pustaka Pelajar, 2000 .

al-Ghazali. Ya Ayyuha al-Walad. Jakarta: alHaramain Jaya Indonesia, 2005.

Giddens, Anthony. Kapitalisme dan Teori Sosial Modern. Diterjemahkan oleh Soeheba. Jakarta: UI Press, 1986.

Hafil, Shodiqil. "Studi atas Zikir Tarekat Masyarakat Urban Jemaah Thariqah Qadiriyah Naqshabandiyah di Jakarta." Jurnal Maraji 1, no. 1 (2014).

Hidayat (et.al). Agama di Tengah Kemelut. Jakarta: Mediacita, 2001.

Horikoshi, Hiroko. Kyai dan Perubahan Sosial. Jakarta: Pusat Pengembangan Pesantren dan Masyarakat (P3M), 1987.

Howell, Julia D. \& Bruinessen, Martin Van. Sufism and The Modern in Islam. LondonNew York: I.B. TAURIS, 1988.

Howell, Julia D. "Revitalised Sufism and the New Piety Movements in Islamic Southeast Asia." In the Routledge Handbook of Religions in Asia. Edited by Bryan S. Turner and Oscar Salemink. Abingdon UK: Routledge, 2015.

"Sufism on the Silver Screen Indonesian in Islamic Televangelism." Journal of
Indonesian Islam 02, no. 02 (2008).

-------. "Pluralist Current and Counter Currents in The Indonesian Mass Media: The case of Anand Khrisna." Dalam Religious Pluralism, State and Society in Asia. New York: 2014.

------- "Introduction: Sufism and Neo Sufisme To Day in Indonesia." Review of Indonesian and Malaysian Affairs 46, no. 2 (2012).

-------. "Sufism and the Indonesian Islamic Revival." The Journal of Asian Studies 60 , no. 3 (2012).

Jati, Wasito Raharjo. "Sufisme Urban di Perkotaan: Konstruksi Keimanan Baru Kelas Menengah Muslim." Jurnal Kajian dan Pengembangan Management Dakwah 05, no. 02 (2015).

Madjid, Nurcholis. "Tasawuf sebagai Inti Keberagamaan." Jurnal Pesantren II, no. 3 (1985).

Naisbitt, John. High Tech, High Touch: Technology and Our Search for Meaning. New York: Broadway, 1999.

Naisbitt, John dan Aburdene, Patricia. Megatrends 2000: New Directions for Tomorrow. London: Siddwick \& Jackson, 1990.

Rachman, Budhy Munawar. "Spiritualitas: Pendekatan Baru dalam Beragama." Komaruddin Studies in Society and History, no. 2 (1960).

Rijal, Syamsul dan Umiarso. "Syariah dan Tasawuf: Pergulatan Integratif Kebenaran dalam Mencapai Tuhan." Jurnal Ushuluddin 25, no. 2 (2017).

Ritzer, George. Sosiologi Ilmu Pengetahuan Berparadigma Ganda. Jakarta: Rajawali Press, 2004.

Riyadi, Abdul Kadir. Antropologi Tasawuf: Wacana Manusia Spiritual dan Pengetahuan. Jakarta: LP3ES, 2014. 
Rubaidi. "Reorientasi Ideology Urban Sufisme di Indonesia terhadap Relasi Guru dan Murid dalam Tradisi Generik Sufisme pada Majelis Shalawat Muhammad di Surabaya." JurnalTeosofi 5, no. 2 (2015).

Schumacher, Fredrich. A Guide for the Perplexed, Rahasia Sukses Hidup Bahagia: Kecerdasan Spiritual (Jakarta: Gramedia Pustaka Utama, 2004).

Secher, H. P. Basic Concepts in Sociology, Contributors: Max Weber. New York: Citadel Press, 1962.

Siroj, Said Aqil. Tasawuf sebagai Kritik Sosial: Mengedepankan Islam sebagai Inspirasi,
Bukan Aspirasi. Bandung: Mizan, 2006.

Sulaiman. "Perubahan Sosial Berbasis Tasawuf: Studi Kasus Fethullah Gülen dan Gülen Movement." Al-Tahrir: Jurnal Pemikiran Islam 16, no. 1 (2016).

Syofrianisda dan M. Arrafie Abduh. "Pengaruh Tasawuf al-Ghazali dalam Islam dan Kristen." Jurnal Ushuluddin 25, no. 1 (2017).

Turner, Bryan S. Teori Sosial Dari Klasik sampai Postmodern. Yogyakarta: Pustaka Pelajar, 2012. 